\title{
Quality Evaluation of Mozzarella Cheese from Different Milk Types
}

\author{
Zedan, I.A.; Abou-Shaloue, Z. and Zaky, S.M. ${ }^{1}$
}

\begin{abstract}
Mozzarella cheeses prepared from buffalo, cow and their mixture (1:1) using commercially available starter cultures (Streptococcus. thermophilus and Lactobacillus. bulgaricus) (1:1). Resultant cheeses were examined when fresh and during storage period at $5 \pm 1^{0} \mathrm{C}$ for 4 weeks. The cow milk Mozzarella cheese tended to be softer, slightly better in flexibility and contained slightly higher moisture, fat and salt contents whereas buffalo milk Mozzarella cheese had higher protein content. Cheeses were also evaluated for meltability (to assess the functionality of cooked cheeses), stretchability, oiling off, microstructure and organoleptic quality. Mozzarella cheese made from buffalo milk showed lower contents of soluble nitrogen and total volatile fatty acids than cheese made from other milks. The electrophoretic pattern of proteins from different milk showed the presence of $\propto_{\mathrm{s}}$ and B-casein as the major components and minor fast and slow moving products. The mobility and relative intensity of the $\propto_{\mathrm{s}}$ bands differs according to the type of milk. The results indicate that proteolysis in the $\propto_{\mathrm{s}}$-fraction occurred in all types of milk. Also cow milk cheese gained the highest score for organoleptic properties, while buffalo milk cheese showed the lowest quality. Mixing cow milk with buffalo milk highly improved the quality of the cheese.
\end{abstract}

\section{INTRODUCTION}

Originally mozzarella is the name of cheese made from high fat water buffalo milk found in South Italy. Also for many decades, however, Italians have made mozzarella cheese from cow and the cheese is highly accepted (Kosikowski; 1986). Mozzarella cheese is defined by Scott (1981) as a member of pasta - filate family (pulled curd, soft cheese). Mozzarella cheese has various shapes like round cake, oval, egg and rectangular shapes.

Mozzarella cheese is a soft unripened cheese variety of the pasta filate family which had its origin in the Buttiplglia region of Italy. The finished cheese is white, soft with a very lively sheen surface and has a unique property called stretchability to form fibers or strings when it is hot. Therefore, it is considered the most suitable cheese variety as a topping on pizza (Kosikowski, 1970).

Mozzarella cheese was first made from buffalo milk and then successfully made from cow and ewe milk. In Egypt, Mozzarella cheese for pizza pie is produced from cow milk in modern dairy plant and from mixed milks in small private dairy plant. The cheese has loaves shape and stored in deep freezers. Mozzarella cheese is a soft unripened cheese variety of the pasta filate family which had its origin in the Buttiplglia region of Italy (Kosikowski, 1970). .

The finished cheese is white, soft with a very lively sheen surface and has a unique property called stretchability to form fibers or strings when it is hot. Therefore, it is considered the most suitable cheese variety as a topping on pizza. (Kosikowski, 1970)

The Egyptian Organization of Standardization and Quality Control ES:1008-14/2005 part 14, defined Mozzarella cheese as a soft cheese, moisture should not exceed $54 \%$, fat not less than $45 \%$ as fat/DM for whole milk cheese, In case of $3 / 4$ of milk fat, fat content of cheese not less than 35\% Fat/DM and moisture content not exceed $57 \%$. As for $1 / 2$ milk fat, Fat $/ \mathrm{DM}$ not less than $25 \%$ and moisture not exceed $60 \%$. Whey proteins in Mozzarella cheese not more than $23 \%$ of total protein.

These functional properties of Mozzarella cheese are influenced by a multitude of factors that include cheese composition particularly moisture, fat content, $\mathrm{pH}$, coagulating enzyme, starter culture, cooking and stretching, salt content and the changes occurring during aging and storage (McMahon et al., 1996). Buffalo milk is ranked second in the world after cow's milk being more than $12 \%$ of the world, milk production (Ahmed et al., 2008). India and Pakistan are producing about $80 \%$ of the world's production of buffalo milk which is used for making different dairy products including soft and hard cheeses (Ahmed et al., 2008). In Pakistan, buffalo milk is $70 \%$ of the total milk produced. Due to high vitamin A, protein and low cholesterol in buffalo milk, it can be more preferred specie in cheese production (Zicarelli, 2004). Mozzarella cheese produced from buffalo milk is highly priced in most of the world. At present the main constraint in commercial exploitation appears to be the paucity of full understanding of the technical aspects in the manufacture of the product. In the present investigation a process has been standardized to manufacture mozzarella cheese of uniform composition from buffalo cow and milk of both. The products are further evaluated for quality to find out the suitable milk source for good quality mozzarella.

\footnotetext{
${ }^{1}$ Department of Dairy Science and Technology,

Faculty of Agricultural, Alexandria University, Egypt.

Received July 8, 2014, Accepted August19, 2014
} 
The aim of this investigation is to study the effect of type of milk on the quality of mozzarella cheese (Cow, Buffalo and mixed cow + buffalo (1:1) $3 \%$ fat).through 28 day of cold storage at $5{ }^{0} \mathrm{C}$.

\section{MATERIALS AND METHODS}

Fresh Cow and buffalo milk used during this study was obtained from the Faculty of Agriculture Experimental Station herd, Alexandria University, milk used in cheese making was standardized to $3 \%$ of fat content. Youghurt starter culture consists of Streptococcus. thermophilus and Lactobacillus. bulgaricus was obtained from Hansen's lab, Denmark. Calf liquid rennet. Dry coarse commercial sodium chloride was obtained from El-Nasr Co, Alexandria, Egypt. Cheese blocks were immersed in solution of 3\% potassium sorbate was used as a fungicide before filling the Mozzarella cheese in polyethylene bags.

\section{Manufacture of Mozzarella cheese}

Mozzarella cheese was made by using Buffalo or cow milk as described by Kosikowski (1982) with some modification (Figure 1). Active lactic starter (Streptococcus salvarius sub sp. thermophilus and Lactobacillus delbreuckii sub sp. bulgaricus) (1:1) was added to the warm milk $37 \pm 2 \mathrm{C}$ in the cheese vat at ratio of $1 \%$ and mixed properly. After $30-45 \mathrm{~min}$ (acidity $0.17 \%$ ), the rennet was introduced at rate of 30 $\mathrm{ml} / 100 \mathrm{Kg}$ milk to finish the coagulation within 30 $40 \mathrm{~min}$. The curd was cut into cubes using American knives, then the cut curds was left in the warm whey for about $50-60 \mathrm{~min}$. with periodic gentle agitation. The whey was drained when its $\mathrm{pH}$ reached 5.8 and the curds gently collected together and kept in the warm cheese vat $(38 \pm 2 \mathrm{C})$ till the curd $\mathrm{pH}$ reached 5.2. The string test gives a rope of 3 meter. At this point the curd block was cut into small pieces and dipped in hot water at $80-85 \mathrm{C}$ and mixed properly for about 5-10 min. using wooden paddle until a smooth plastic mass obtained and formed into braids. The cheese salted in $18-20 \%$ cold brine solution $\left(6 \pm 2{ }^{\circ} \mathrm{C}\right)$ for 2 hours. The cheese braids removed from the brine, dried on muslin and packaged in polyethylene bags. The resultant cheese was analyzed fresh and during storage at $5 \pm 1{ }^{0} \mathrm{C}$ for chemical, rheological, microstructure and organoleptical properties.

\section{Methods of analysis \\ Chemical analysis}

Moisture content of milk, whey, kneading water and cheese was determined according to the AOAC (2000). For the estimation of titratable acidity of milk and whey, $10 \mathrm{ml}$. were titrated with $\mathrm{NaOH} \mathrm{N} / 9$ using phenolphthalein as indicator. In the case of cheese, titratable acidity was determined according to the method described by Ling (1963). The results were expressed as lactic acid percentage. The $\mathrm{pH}$ value of cheese was determined by using glass electrode $\mathrm{pH}-$ meter (Model 810 Fisher Scientific) according to AOAC (2000). For fat determination the conventional Gerber's method used for milk, whey, kneading water and cheese as described by AOAC (2000). The modified Volhards method as described by Kosikowski (1970) was used to determine the salt content in cheese. The calcium content in milk, whey, stretching water and cheese was determined according to the method described by Abd-El-Raheem (1957), using an atomic absorption spectroscopy. Total nitrogen (TN) in milk, whey and kneading water was determined by using the semi micro Kjeldahl methods as described by Rowland (1938). The total nitrogen and water soluble nitrogen contents of cheese were estimated as described by Ling (1963). For the determination of total volatile fatty acids (TVFA) in cheese, $15 \mathrm{gm}$. of the sample was steam distilled as described by Ostoeux et al, (1958) and modified by El- Nemr (1968). Values were expressed as $\mathrm{ml}$ of $0.1 \mathrm{~N} \mathrm{NaOH} / 100 \mathrm{~g}$ cheese.

\section{Rheological properties}

Meltability (mm), of cheese was measured in duplicate by using the melting test tube as described by Olson and Price (1958) with the modification of Rayan et al, (1980). A cylinder of cheese sample $(15 \pm 0.2 \mathrm{~g})$ was put into Pyrex glass tube. $30 \mathrm{~mm}$ in diameter and $250 \mathrm{~mm}$ long and reference line was marked on the tube aligned with the front edge of cheese sample. The tube was immediately placed in horizontal position in an oven at $110 \mathrm{C}$ for 30 min. the distance of flow from the reference line to the leading edge of the melted cheese was quickly measured and recorded in $\mathrm{mm}$ as cheese meltability.

Stretchability test $(\mathrm{cm})$, of Mozzarella cheese was evaluated by Sabikhi and Kanawjia (1992) method as the following procedure. A $250 \mathrm{ml}$ beaker was filled to $3 / 4$ its volume with hot water at $85 \mathrm{C}$. About $10 \mathrm{gm}$ of the cheese was put in the beaker and allowed to remain immersed for a minute. A glass rod was immersed in the center of the molten mass of cheese and the cheese lifted with the rod. The length of the thread formed was measured as $\mathrm{cm}$. longer threads indicated better stretching characteristics. The stretchability was graded on a 5 point arbitrary scale where 5 represented the best product.

Oiling off (ratio). The fat leakage method as described by Ghosh and Singh (1992) was used to determine the oiling off ratio. Four cheese disks $(25 \mathrm{~mm}$ in diameter and $4 \mathrm{~mm}$ thick) for each treatment were placed on Whatman No. 42 filter paper and placed in an atmospheric oven at $100 \mathrm{C}$ for $10 \mathrm{~min}$, the area of each oily ring was measured with a planimeter. 
Raw milk (cow, buffalo or mixed milk (1:1))

Standardization to $3 \%$ fat

Adding of 1\% starter for 30 min (Streptococcus salvarius sub sp. thermophilus and Lactobacillus delbreuckii sub sp. bulgaricus)

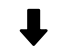

Renneting at $37^{\circ} \mathrm{C}(40-50 \mathrm{~min})$

$\downarrow$

Cutting the curd $1 \times 1 \times 1 \mathrm{~cm}-$ stirring the curd

$\downarrow$

Scalding to $40-42^{\circ} \mathrm{C}$ through $30 \mathrm{~min}$

$\downarrow$

Drainage- off the whey

The cheddaring is off and the curd was left $5 \mathrm{~min}$

The curd in muslin and left for $15 \mathrm{~min}$

The string test 3 meter $(\mathrm{pH}=5.2)$

Kneading of the curd (hot water at $75-80^{\circ} \mathrm{C}$ for $5 \mathrm{~min}$ )

The hot curd formed into Braids

The cheese were salted in cold brine $20 \% \mathrm{Nacl}$ for 2 hour

The Braided cheese were left on dry clothes

The cheese was rubbed by $3 \%$ potassium sorbate

Packing and storage (At $5 \pm 1{ }^{\circ} \mathrm{C}$ for 28 days for analysis)

Figure 1. Flow chart of Mozzarella cheese making from different milk 
(Oiling off was recorded by compared the area of fat leakage with the area around the original disk). The fat leakage was reported as a ratio of $\mathrm{A} / \mathrm{B}$ where, $\mathrm{A}=$ Area of fat ring, $\mathrm{B}=$ Area of original disc.

\section{Cheese microstructure}

Scanning electron microscopy was performed using modified methods of Tamime et al,(1990). Fresh Mozzarella cheese sample was put into small tube for dry freezing in the apparatus Zirbus Vaco 5- 11-D at $80 \mathrm{C}$ for 24 hours under pressure of $0.5 \mathrm{~m}$ bar and coated with gold up to a thickness of $400 \mathrm{~A}$ in a sputtercoating unit (JFC-1100 E). Observations of sperm morphology in the coded specimens were performed in a Jeol JSM- 5300 scanning electron microscope operated between 15 and $20 \mathrm{KeV}$.

\section{Polyacrylamide gel electrophoresis}

Alkalin native urea-PAGE, Gel electrophoresis was performed according to the method of Andrews (1983) with separation gel of $\mathrm{T}=12.5 \%, \mathrm{C}=4 \%$ and $4.5 \mathrm{M}$ urea (separation gels buffer $4.6 \%$ tris and adjusted by $\mathrm{HCl}$ to $\mathrm{pH}$ 8.9). The apparatus buffer was $15 \mathrm{~g}$ tris $+73 \mathrm{~g}$ glycin in $5 \mathrm{~L}$ water and gels were run at approximately $25 \mathrm{v} / \mathrm{cm}$ for about $75-90 \mathrm{~min}$, till the Bromophenol blue tracing dye was close to the bottom of the slab. Staining was caring out for $1 \mathrm{~h}$ in $0.25 \%$ (w/v) commessie blue $\mathrm{G}$ 250 in $50 \%$ methanol containing $12.5 \%$ TCA and destining in $7 \%$ acetic acid. Sample buffer was $10 \%$ staking gel buffer containing $8 \mathrm{M}$ urea and $2 \%$ of 2 mercaptoethanol, and $0.01 \%$ Bromophenol blue $0.010 \mathrm{~g}$ of casein was dissolved in $1 \mathrm{ml}$ sample buffer and $5 \mathrm{ul}$ of all the treatment were applied to the gel.

\section{Organoleptic evaluation}

Samples from fresh and stored Mozzarella cheese were organoleptically evaluated according to the scheme described by Nelson and Trout (1956) as follows: 15 points for appearance (condition of surface presence of cracks and moulds). 35 points for body and texture (dry, rubbery, pasty, graining, greasy or spongy) and 50 point for the flavor (bitterness, salty taste, acid taste or off flavors).

\section{Statistical analysis}

Statistical analysis of the obtained data was done using the data were fed to the computer and analyzed using IBM SPSS software package version 20.0.(2) Quantitative data were described using range (minimum and maximum), mean, standard deviation and median. Comparison between two independent population were done using independent t-test while more than two population were analyzed using F-test (ANOVA) and Post Hoc test (LSD) Significance of the obtained results was judged at the $5 \%$ level. According to Kotz et al.,(2006).

\section{RESULTS AND DISCUSSIONS}

\section{Chemical composition of cheese milk}

Table (1) shows the chemical composition of the three milks. It is clear that buffalo milk had approximately the double percentage of fat cow milk and higher protein. The blending of cow milk with buffalo milk raised the T.S, fat and protein contents of mixed milk.

Standardization of cow and buffalo milk to $3 \%$ fat led to marked decrease in T.S and little decrease of protein.

Effect of milk type on the chemical composition of Whey, kneading water and fresh cheese.

The gross chemical compositions of whey, kneading water and fresh cheese are shown in Table (2). Amount of released whey of cow milk (26.2L) was higher than those of buffalo milk (25.5 L.), while whey of mixed milk was (25.9 L.).

As it is expected, T.S of buffalo milk whey was higher $(6.784 \%)$ than cow milk whey total solid (5.875). This is due to the higher protein content of buffalo milk than cow milk protein. The addition of buffalo milk to cow milk raised the T.S of whey of mixed milk (6.154\%) as compared with cow milk.

Table 1. The chemical composition of standardized cheese milk (buffalo, cow and mixed milk)

\begin{tabular}{lccc}
\hline \multirow{2}{*}{ Components } & \multicolumn{2}{c}{ Type of Milk } \\
\cline { 2 - 4 } & Buffalo milk & Cow milk & Mixed milk \\
\hline Acidity \% & 0.16 & 0.16 & 0.17 \\
\hline PH & 6.60 & 6.60 & 6.70 \\
\hline Fat \% & 3.00 & 3.00 & 3.00 \\
\hline Protein \% & 4.76 & 3.40 & 4.25 \\
\hline Total solid \% & 13.38 & 11.52 & 12.63 \\
\hline
\end{tabular}


Table 2. Effect of type of acidulant on the gross chemical composition of whey, kneading water and fresh cheese

\begin{tabular}{|c|c|c|c|c|c|c|c|c|c|}
\hline Treatments & Components & $\begin{array}{c}\text { Amo } \\
\text { unt } \\
(\mathrm{Kg}) \\
\end{array}$ & $\begin{array}{c}\text { Total } \\
\text { solid } \\
\% \\
\end{array}$ & $\begin{array}{c}\text { Fat } \\
\%\end{array}$ & $\begin{array}{c}\text { Fat/ } \\
\text { DM } \\
\% \\
\end{array}$ & $\begin{array}{c}\text { Total } \\
\text { Nitrogen } \\
\% \% \\
\end{array}$ & $\begin{array}{c}\text { Total } \\
\text { Protein } \\
\% \\
\end{array}$ & $\begin{array}{c}\text { Total } \\
\text { Protein } \\
/ \text { DM \% } \\
\end{array}$ & $\begin{array}{c}\text { Calcium } \\
\text { Content } \\
\% \\
\end{array}$ \\
\hline \multirow{3}{*}{ Buffalo milk } & Whey & 25.50 & 6.784 & 0.6 & 8.844 & 0.258 & 1.646 & 24.262 & 0.217 \\
\hline & Kneading water & 15.00 & 0.972 & 0.5 & 51.440 & 0.071 & 0.408 & 41.975 & 0.052 \\
\hline & Fresh cheese & 3.700 & 49.645 & 17.9 & 36.055 & 4.132 & 26.362 & 53.101 & 3.170 \\
\hline \multirow{3}{*}{ Cow milk } & Whey & 26.20 & 5.875 & 0.5 & 8.510 & 0.150 & 0.957 & 16.289 & 0.160 \\
\hline & Kneading water & 15.00 & 0.674 & 0.4 & 59.347 & 0.035 & 0.223 & 33.086 & 0.041 \\
\hline & Fresh cheese & 3.200 & 48.172 & 21.7 & 45.046 & 3.532 & 22.534 & 46.778 & 2.463 \\
\hline \multirow{3}{*}{ Mixed milk } & Whey & 25.90 & 6.154 & 0.5 & 8.124 & 0.200 & 1.276 & 20.734 & 0.195 \\
\hline & Kneading water & 15.00 & 0.875 & 0.5 & 57.142 & 0.057 & 0.319 & 36.457 & 0.045 \\
\hline & Fresh cheese & 3.500 & 48.853 & 19.5 & 39.915 & 3.942 & 25.149 & 51.478 & 2.736 \\
\hline
\end{tabular}

Abdel- Kader (1993) observed that losses of fat and protein were higher in buffalo milk treatment and its admixtures; this is may be due to the larger fat globules of buffalo milk fat as compared with those of cow and goat milk.

Sabikhi and Kanawjia (1992) observed that the T.S. in the whey had a minimum of 7.26 in the $1: 1$ blend of goat and buffalo milk, whereas the $3: 1$ blend and the control exhibited a loss of 7.48 and $7.56 \%$, respectively. The losses in the 1:3 blends and the pure goat milk system were 7.76 and $8.23 \%$ in that order. This explains the decrease of total solid recovery in the milk system containing more than $50 \%$ of goat milk.

From the same Table (2) the losses of fat and protein into whey and kneading water were higher in buffalo milk treatment than cow milk treatment. This is may be due to the larger fat globules of buffalo milk than those of cow milk at mean time protein content of standardized buffalo milk is higher than those of cow milk. Mixed milk treatment took values less than buffalo milk and higher than cow milk treatment.

El- Zoghby (1988) run a comparative study between cow milk (4\%fat) and mixed milk, cow: buffalo (1:1having $4 \%$ fat) and he found $\%$ total fat loss and fat recovery $(22.75 / 77.25)$ and $(23.30 / 76.70)$ for cow and buffalo milk respectively. He found also that respective $\%$ total protein loss and protein recovery \% were $(23.82 / 76.18)$ and $(23.61 / 74.39 \%)$ respectively.

From kneading point of view, buffalo and mixed milk curds were kneaded at $80^{\circ} \pm 2^{\circ} \mathrm{C}$ as well kneading time reached 7 minutes.

Fat content of buffalo milk cheese was less than those of cow and mixed milk treatments, because the losses into whey and kneading water were higher. Contrary to fat content, protein content of the cheese of buffalo milk was markedly higher than those of cow and mixed milks. This is due to the higher protein content of buffalo milk as well the larger micelles of buffalo milk casein.

Udabage et al. (2001) studied the effects of ionic calcium on rennet coagulation. They found that citrate and EDTA completely inhibited gelation; this was reversed by adding calcium chloride. They suggested that, when the minimum requirements for colloidal calcium phosphate removal and casein were met, the coagulation time decreased as ionic calcium increased. Therefore, an optimum concentration of ionic calcium is necessary for the correct curd firmness and cutting time. For example, it could be increased by the addition of calcium chloride to milk to enhance the curd firmness and to shorten the RCT.

\section{Recovery of fat and protein contents in fresh cheese}

To compare between the three treatments fat and protein losses were calculated in whey and kneading water, as well the retained fat and protein in fresh cheese.

From table (3) it is clear that losses of fat are markedly higher in buffalo milk treatment than cow milk treatment. On the other hand, recovery of fat $(77.15 \%)$ is higher in cow milk treatment than buffalo milk treatment $(73.58 \%)$. Mixing of cow milk with buffalo milk decreased losses of fat in whey and kneading water, and increased fat recovery to reach $(75.83 \%)$.

Total losses of fat in whey and kneading water were $25.33,21.22$ and $22.66 \%$ for buffalo, cow and mixed milk treatments.

El-zougby (1988) found similar trend of results being $22.0,14.76$ and $20.0 \%$ for cow, buffalo and $(\mathrm{C}+\mathrm{B}$ 1: 1) while recoveries were $86.1,71.67$ and 80.44 respectively.

Abdel- Kader (1993) found that fat losses were higher in buffalo milk treatment followed by mixed 
milk and were relatively less in cow milk and he added that acidifying the different types of milk at low $\mathrm{pH}$ increased the loss of fat and protein either in whey of kneading water during Kachkaval cheese making.

Similar to fat, protein losses were calculated in whey and kneading water Table (3). From the same table losses of protein in whey and kneading water was similarly calculated. Losses in whey were higher than losses of protein in kneading water for all treatments.

The highest losses of protein were for buffalo milk treatment, and the lowest was for cow milk treatment. The additions of cow milk cheese to buffalo milk cheese decreased the total losses of protein. Recovery protein values were $68.30,70.69$ and $69.03 \%$ for buffalo, cow and mixed milk treatments respectively.

Sabikhi and Kanawjia (1992) observed that the T.S. recovery increased from $52.01 \%$ in the control buffalo milk to $52.68 \%$, with increasing level of mixing goat milk, up to the extent of $50 \%$ level. Further increase in the goat milk proportion exhibited a downward trend in the T.S. recovery.

\section{Effect of milk type on the cheese yield.}

The yield of cheese was calculated for fresh cheese and results were tabulated in Table (4).

From Table (4) it is clear that buffalo milk cheese gave the highest yield (12.33\%), while cow milk cheese gave the lowest yield $(10.66 \%)$. Admixing the buffalo milk with cow milk raised the yield of cow milk treatment to reach $(11.66 \%)$. The highest yield of buffalo milk is due to the higher T.S of milk cheese (13.38\%) as compared with cow milk cheese (11.52\%).

Similar results were obtained by Sabikhi and Kanawjia (1993) who found from $100 \%$ buffalo milk yield was $(15.44 \%)$ and (15.20\%) for admixed B + G (1: 1).

El-Zougby (1994) produced mozzarella cheese from $\mathrm{B}, \mathrm{C}$ and $\mathrm{G}$ milk $\mathrm{B}+\mathrm{C}(1: 1), \mathrm{B}+\mathrm{G}(1: 1), \mathrm{C}+\mathrm{G}(1: 1) 3 \%$ fat. The yield of fresh cheese were, 11.62, 8.95, 7.93, $10.50,10.35,8.37$ and $9.15 \%$ for $\mathrm{B}, \mathrm{C}, \mathrm{G}$ and $\mathrm{B}+\mathrm{C}$, $\mathrm{B}+\mathrm{G}, \mathrm{C}+\mathrm{G}$ and $\mathrm{B}+\mathrm{C}+\mathrm{G}$ respectively.

Ghosh and singh (1996) observed that the cow and buffalo milk had significant effect $(\mathrm{P}<0.01)$ on the yield of mozzarella cheese. The yield of buffalo milk cheese was higher $(14.38 \%)$ than that of cow milk cheese $(12.40 \%)$.

The buffalo milk is richer in fat and protein especially casein Ahmed et al., (2008) and casein is the major constituent that influences the cheese yield and chemical composition of milk.

Effect of milk type on chemical composition of Mozzarella cheese during 28 days of storage at $5 \pm 1{ }^{0} \mathrm{C}$

Table 3. Recovery of fat and protein contents in the fresh cheese during Mozzarella cheese making as affected by milk type

\begin{tabular}{lccc}
\hline \multicolumn{1}{c}{ Constituents } & Buffalo milk & Cow milk & Mixed milk \\
\hline Amount of fat in milk $(\mathrm{Kg})$ & 0.9 & 0.9 & 0.9 \\
\hline Fat loss in whey $(\mathrm{Kg})$ & 0.153 & 0.131 & 0.129 \\
\hline Fat loss in kneading water $(\mathrm{Kg})$ & 0.075 & 0.060 & 0.075 \\
\hline Total fat loss\% & 25.33 & 21.22 & 22.66 \\
\hline Amount of fat in fresh cheese $(\mathrm{Kg})$ & 0.662 & 0.694 & 0.682 \\
\hline Fat recovery \% & 73.58 & 77.15 & 75.83 \\
\hline Amount of Protein in milk $(\mathrm{Kg})$ & 1.428 & 1.020 & 1.275 \\
\hline Protein loss in whey $(\mathrm{Kg})$ & 0.419 & 0.250 & 0.330 \\
\hline Protein loss in kneading water $(\mathrm{Kg})$ & 0.061 & 0.033 & 0.047 \\
\hline Total Protein loss\% & 33.61 & 27.74 & 29.56 \\
\hline Amount of Protein in fresh cheese $(\mathrm{Kg})$ & 0.975 & 0.721 & 0.880 \\
\hline Protein recovery \% & 68.30 & 70.69 & 69.03 \\
\hline
\end{tabular}

Table 4. The yield of cheese as affected by milk type

\begin{tabular}{lcccc}
\hline \multicolumn{1}{c}{ Type of milk } & $\begin{array}{c}\text { Amount of } \\
\text { whey } \mathbf{( K g )}\end{array}$ & $\begin{array}{c}\text { Amount of milk } \\
(\mathbf{K g})\end{array}$ & $\begin{array}{c}\text { Amount of } \\
\text { curd (Kg) }\end{array}$ & Yield \% \\
\hline Buffalo milk & 25.5 & 30 & 3.70 & 12.33 \\
\hline Cow milk & 26.2 & 30 & 3.20 & 10.66 \\
\hline Mixed of Buffalo and Cow & 25.9 & 30 & 3.50 & 11.66 \\
\hline
\end{tabular}




\section{Titratable acidity and $\mathrm{PH}$ values.}

From table (5) it is clear that as storage time advanced, acidity increased, while $\mathrm{pH}$ values decreased. Acidity $/ \mathrm{pH}$ of fresh cheese were $(0.76 / 5.23),(0.82 / 5.16)$ and $(0.79 / 5.2)$ for buffalo, cow and mixed milk respectively. These values were (1.03/4.91), (1.11/4.79) and $(1.05 / 4.89)$ for 28 days old cheese respectively. The general trend of these results was in agreement with that found by El-Abbassy et al (1991).

Titratable acidity and $\mathrm{PH}$ values for admixtures of buffalo and goat milk were determined by Sabikhi and Kanawjia (1992) results obtained for acidity and $\mathrm{PH}$ were $\quad(0.357 / 5.76), \quad(0.363 / 5.62), \quad(0.354 / 5.591)$ ,$(0.362 / 5.64)$ and $(0.370 / 5.68)$ for $100 \%$ buffalo, (3:1), $(1: 1),(1: 3)$ and $100 \%$ goat milk when fresh cheese respectively.

El-Zoughby (1994) found that acidity of buffalo milk cheese was less than those of cow and goat milk cheese and also the development of acidity of such cheese during storage was slower than those of cows and goats milk cheese. This could be explained on the basis that buffalo milk cheese possesses a higher buffering capacity than those of cow milk Abdel- Kader (1993).

\section{Total solid content.}

Total solid of cheese from different treatments were tabulated in table (5). The lower total solid content was found for cow milk cheese in comparison with buffalo milk cheese. Total solid of fresh cheese and 28 days old cheese were (49.645/50.785), (48.172/49.284) and (48.853/49.992) for buffalo, cow and mixed milk respectively.

El-Zoughby (1994) showed that the lower moisture content was found for buffalo milk cheese and also the blending of buffalo milk to the other types of milk decreased the moisture content of cheese resulted from the admixtures milk cheese.

Helal (2006) found that the moisture content was ranged between $50.31 \%$ and $54.13 \%$ and between $46.33 \%$ and $49.81 \%$ for mozzarella chesses made from cow and buffalo milk respectively. Moisture content of buffalo cheeses was always lower than that of cow cheeses.

Sameen, et al., (2010) observed that the moisture and protein content of cheese significantly affected by the difference in milk sources, fat level, starter cultures during ripening. The $\mathrm{pH}$ and acidity also influenced by all variables except fat level whereas the fat content of cheese only influenced by fat levels of milk.

\section{Fat content \& Fat/DM.}

From the same table fat content is higher in cow and mixed milk cheese as compared with buffalo milk cheese. This is may be due to the higher losses of fat in whey and kneading water. Fat/DM for fresh and 28 days old cheese were $\quad(36.055 / 37.412), \quad(45.046 / 45.653) \quad$ and $(39.915 / 41.606 \%)$ for buffalo, cow and mixed milk cheese respectively. These results in agreement with ElZoughby (1994) showed that the as storage period was advanced the fat content increased. This phenomenon is due to the gradual loss of moisture content during storage.

El- Batawy, et al., (2004) observed that the cow milk Mozzarella cheese tended to be softer, slightly better in flexibility and contained slightly higher moisture, fat and salt content whereas buffalo milk Mozzarella cheese had higher protein content.

Helal(2006) found that the fat content was ranged between 21.2 and $23.1 \%$ and between 20.1 and $21.9 \%$ for mozzarella cheeses made from cow and buffalo milk, respectively. Fat content of buffalo cheeses was always lower than that of cow cheeses.

\section{Salt \& salt/DM.}

From the same Table (5) salt content ranged between 1.162 and $1.345 \%$, as the storage period advanced salt content apparently increased because of the increase in total solid this was reported by Sabikhi and Kanawjia (1992). Salt /DM of fresh and 28 days old cheese stored at $5 \pm 1{ }^{0} \mathrm{C}$ were $(2.709$ /3.109), (2.428 $12.848)$ and $(2.513 \% / 2.808 \%)$ for buffalo, cow and mixed milk respectively.

Abdel- Kader, (1993) found that there is no definite effect of type of milk on salt content of cheese. The increase in salt content as storage period increased is owing to the gradual decrease of moisture during storage at $4 \mathrm{C}$.

\section{Calcium contents.}

Also table (5) included the calcium content of fresh and 28 days old cheese .Similar to the other components, as storage period advanced, the total calcium increased .Buffalo milk cheese had higher calcium content than cow milk cheese. Also the addition of buffalo milk to cow milk raised the calcium content of ad mixture cheese. The obtained results are in agreement with those obtained by Abdel-kader (1993) and El-Zoughby, (1994).

Ghosh and Singh (1996) observed that cow milk cheese contained slightly higher moisture than the cheese made from buffalo milk but the difference was 
not significant $(\mathrm{P}>0.05)$.

Table 5. Effect of milk type on acidity, $\mathrm{pH}$, Salt, total solid and fat contents of Mozzarella cheese during 28 days of storage at $5 \pm 1^{0} \mathrm{C}$

\begin{tabular}{|c|c|c|c|c|}
\hline Parameter & Storage Period per day & Buffalo milk & Cow milk & Mixed milk \\
\hline \multirow{3}{*}{ Acidity \% } & Fresh & 0.76 & 0.82 & 0.79 \\
\hline & 14 & 0.85 & 0.94 & 0.88 \\
\hline & 28 & 1.03 & 1.11 & 1.05 \\
\hline \multirow{3}{*}{$\mathrm{PH}$ value } & Fresh & 5.23 & 5.16 & 5.2 \\
\hline & 14 & 5.09 & 4.96 & 5.02 \\
\hline & 28 & 4.91 & 4.79 & 4.89 \\
\hline \multirow{3}{*}{$\mathrm{TS} \%$} & Fresh & 49.645 & 48.172 & 48.853 \\
\hline & 14 & 50.425 & 48.863 & 49.559 \\
\hline & 28 & 50.785 & 49.284 & 49.992 \\
\hline \multirow{3}{*}{ Fat $\%$} & Fresh & 17.9 & 21.7 & 19.5 \\
\hline & 14 & 18.6 & 22.2 & 20.3 \\
\hline & 28 & 19.0 & 22.5 & 20.8 \\
\hline \multirow{3}{*}{ Fat / DM \% } & Fresh & 36.055 & 45.046 & 39.915 \\
\hline & 14 & 36.886 & 45.433 & 40.961 \\
\hline & 28 & 37.412 & 45.653 & 41.606 \\
\hline \multirow{3}{*}{ Salt \% } & Fresh & 1.345 & 1.170 & 1.228 \\
\hline & 14 & 1.462 & 1.287 & 1.345 \\
\hline & 28 & 1.579 & 1.404 & 1.404 \\
\hline \multirow{3}{*}{ Salt / DM \% } & Fresh & 2.709 & 2.428 & 2.513 \\
\hline & 14 & 2.899 & 2.633 & 2.713 \\
\hline & 28 & 3.109 & 2.848 & 2.808 \\
\hline \multirow{2}{*}{ Total Calcium \% } & Fresh & 0.712 & 0.587 & 0.658 \\
\hline & 28 & 0.806 & 0.631 & 0.712 \\
\hline
\end{tabular}

Therefore, the two types of milk with fat content had no significant on the moisture content of Mozzarella cheese. The fat content was relatively higher $(24.80 \%)$ in the cheese made from cow milk whereas the protein content was higher in the cheese from buffalo milk. Higher moisture, fat and salt content were recorded in cow milk cheese, whereas, protein and ash content were higher in buffalo milk cheese. This is due to the higher protein and mineral content of buffalo milk. Lower moisture retention in the buffalo cheese could be attributed either to the higher protein and mineral content.

Effect of milk type on the total nitrogen, soluble nitrogen and total volatile fatty acids of mozzarella cheese

\section{Total nitrogen (TN)}

From the table (6) it could notice that total nitrogen of buffalo milk cheese was higher than other treatments. The apparent increase in $\mathrm{TN}$ is owing to the losses of some moisture and increasing of T.S. Total nitrogen for fresh and 28 days old cheese were (4.132/4.275), $(3.532 / 3.646)$ and $(3.942 \% / 4.079 \%)$ for buffalo, cow and mixed milk respectively. The results are in according with those observed by EL-Zoughby (1994) and Abbas (2003) who found that total nitrogen of buffalo milk cheese was higher than other treatments and also blending it with other milk raised markedly the TN of the admixture milk cheese. Also show that decomposition of buffalo protein was slower than those of cows and goats milk. Also the addition of buffalo milk to other milk led the admixtures to slow their protein decomposition.

\section{Soluble nitrogen (SN)}

As indicated in table (6), although the cheese was kept at $4{ }^{0} \mathrm{C}$, the soluble nitrogen content gradually increased as time of storage was advanced. To compare between the hydrolysis of the three treatments SN/TN was taken as a measure of protein coefficient hydrolysis. Results show that decomposition of buffalo protein was slower than those of cow and mixed milk. Fresh cheeses have SN/TN values 4.138, 7.248 and 5.200\% for buffalo, cow and mixed cheeses respectively. Respective values for 4 weeks old cheese were $6.385,11.711$ and $10.051 \%$ respectively.

Abdel-kader (1993) found the same trend for nitrogen fractions of Kachkaval cheese made from 
buffalo or cow milk and either mixtures. He reported that cow milk cheese showed higher values for water soluble nitrogen (WSN) and non protein nitrogen (NPN) than mixed milk or buffalo milk cheese. These results are also in common with that reported by ELZoughby (1994) and Abbas (2003).

Helal(2006) found that the soluble nitrogen (SN) content was varied from $0.24 \%$ to $0.27 \%$ and from $0.13 \%$ to $0.18 \%$ for cheeses made from cow and buffalo milk, respectively.

El-Batawy, (2004), found that the slight increase was observed in the TN of the UF-Mozzarella cheese for different treatment. These results are expected as a result of the concentration of casein and the retaining of whey protein in the retentate by the ultrafiltration process. Also the SN/TN\% in traditional Mozzarella cheese exhibited higher values than UF- Mozzarella cheese. The SN/TN\% of mozzarella cheese made from buffalo milk was lower than that of cow milk or that of their mixture $(1: 1)$. The corresponding values of SN/TN\% when concentrated milk was used, gave the same trend.

\section{Total volatile fatty acids (TVFA)}

During manufacturing and ripening of cheese most of lactose is fermented mainly into lactic acid and other products. Total volatile fatty acids expressed as $\mathrm{ml}$. of $0.1 \mathrm{~N} \mathrm{NaOH} / 100 \mathrm{gm}$ of the cheese as affected by milk types were tabulated in table (6). The TVFA of cow milk cheese was higher (8.0) for cow milk cheese and the lowest (3.3) for buffalo milk. Mixing both milks together slightly increase the TVFA to (4.0). By the end of storage values raised to be 12.0, 20.0 and 18.0 for buffalo, cow and mixed milk respectively .It is well known that micelles of buffalo milk casein is larger as well buffalo milk had higher buffer capacity which led to slow protein and fat hydrolysis, as compared with cow milk casein

Cow cheeses had three to four times TVFA higher than cheeses made from buffalo milk. These finding are similar to those obtained by El-Zoghby (1994) and Abbas (2003) found that the TVFA content was increased as time of storage was advanced for all treatments. Also type of milk has noticeable effect on TVFA being the lowest for buffalo milk and the highest for goat milk cheese. The higher content of TVFA of goat milk cheese could be due to the higher level of short chain fatty acids content of goat milk.

El-Batawy,(2004) showed that TVFA increased with progressing storage in all samples. However, the rate of increase in TVFA varied considerably among the treatment. UF-Mozzarella cheese either fresh or stored contained lower TVFA than that of traditional one. This may be due to the inhibition of lipase enzyme in UFcheese and the higher moisture content in the traditional method, which has active lipase. The TVFA content of mozzarella cheese made of normal or concentrated cow milk was higher than that in the corresponding cheese made of either buffalo milk or from the mixture of the two kinds of milk (1:1).

Helal(2006) found that the total volatile fatty acids content was ranged from 6.6 to 8.6 and from 2.0 to 2.3 $(\mathrm{ml} \mathrm{NaOH} 0.1 \mathrm{~N} / 100 \mathrm{gm}$ of cheese) for cheeses made from cow and buffalo milk, respectively.

Ismail and Abdel- Kader (2012) showed that manufacture of Mozzarella cheese from buffalo milk led to slow in the protein decomposition of cheese. Also, the TVFA content of Mozzarella cheese made from cow or goat milk was higher than that made from buffalo milk.

Table 6. Effect of milk type on total nitrogen, soluble nitrogen and TVFA of Mozzarella cheese during 28 days of storage at $5 \pm 1{ }^{\circ} \mathrm{C}$

\begin{tabular}{|c|c|c|c|c|}
\hline Parameter & Storage Period per day & Buffalo milk & Cow milk & Mixed milk \\
\hline \multirow{3}{*}{ TN\% } & Fresh & 4.132 & 3.532 & 3.942 \\
\hline & 14 & 4.221 & 3.602 & 4.021 \\
\hline & 28 & 4.275 & 3.646 & 4.079 \\
\hline \multirow{3}{*}{ TN/DM \% } & Fresh & 8.323 & 7.332 & 8.069 \\
\hline & 14 & 8.370 & 7.371 & 8.113 \\
\hline & 28 & 8.417 & 7.397 & 8.159 \\
\hline \multirow{3}{*}{$\mathrm{SN} \%$} & Fresh & 0.171 & 0.256 & 0.205 \\
\hline & 14 & 0.228 & 0.342 & 0.273 \\
\hline & 28 & 0.273 & 0.427 & 0.410 \\
\hline \multirow{3}{*}{$\mathrm{SN} / \mathrm{TN} \%$} & Fresh & 4.138 & 7.248 & 5.200 \\
\hline & 14 & 5.401 & 9.494 & 6.789 \\
\hline & 28 & 6.385 & 11.711 & 10.051 \\
\hline \multirow{2}{*}{$\begin{array}{c}\text { TVFA ml NaOH } 0.1 \mathrm{~N} \\
/ 100 \mathrm{~g} \text { of cheese }\end{array}$} & Fresh & 3.3 & 8.0 & 4.0 \\
\hline & 14 & 7.3 & 15.3 & 10 \\
\hline
\end{tabular}


Effect of milk type on rheological properties of mozzarella cheese

\section{Meltability of cheese}

There are standards for functional properties such as meltability and its relation to the quality specification. As meltability increased, the quality of the Mozzarella cheese increased. Results of meltability were tabulated in table (7). A storage period of Mozzarella cheese increased, meltability parallel, was increased in all treatments. On the other hand type of milk had a marked effect on meltability, although the fat \% was the same for all of treatments being $3 \%$ values of meltability of fresh cheese were 65,117 and $90 \mathrm{~mm}$. for buffalo, cow and mixed milk respectively. Respective values for 28 days old cheese were 105,169 and 138 $\mathrm{mm}$. respectively. These results are in line with those obtained by Sabikhi and Kanawjia (1992). found that the metability and fat leakage in mozzarella cheese increased consistently with the increase in goat milk levels. Ghosh and singh (1992) studied the effect of packaging on melting of Mozzarella cheese stored in a refrigerator during 49 days. Results showed the same trend concerning increasing the meltability values during storage while packaging has no marked significant effect on meltability.

El-Zoughby (1994) found that buffalo milk fresh cheese had the lowest meltability among the other types of cheese from different treatments and reached one half of cow milk fresh cheese. Also goat milk fresh cheese gave lower meltability value as compared with cow milk cheese. On the other hand the addition of cow or goat milk to buffalo milk led to improve meltability of the resultant cheese. The addition of buffalo milk to goat milk slightly lowered the meltability of the resultant blend cheese (buffalo + goat milk cheese) compared with that made from goat milk while the addition of cow milk to the goat milk raised the meltability of the admixture cow + goat milk cheese.

Ghosh,and Singh,(1996) found that the melting and fat leakage of cheese made from cow milk was more than that of made from buffalo milk.

Mostafa, et al., (1996) studied the metability of cheese as affected by type of milk. Mozzarella cheese showed increased meltability with advanced storage in all treatment. Fresh cheese from buffalos milk showed the lowest, while that from cow milk showed the highest meltability. On the other hand, the addition of cow or goat milk to buffalo milk improved the meltability of the resultant cheese.

Abbas (2003) and Helal (2006) found that buffalo milk cheese showed the lowest meltability in all treatments especially at zero time.

Sameen, et al., (2008) observed that the cheese from mixture of cow and buffalo milk had higher meltability and sensory scores, as compared with buffalo milk cheese, therefore it is more suitable for pizza toping than cheese from buffalo.

\section{Stretchability of cheese}

Stretchability defined as the ease and extent to which melted Mozzarella can be drawn to form string Gunasekaren and Mehmet (2003). From table (7) the Stretchability values of cheese expressed as $(\mathrm{cm})$ after fresh and 28day of storage at $5 \pm 1{ }^{0} \mathrm{C}$ were $(20 / 82)$, $(75 / 116)$ and $(62 \mathrm{~cm}$ and $96 \mathrm{~cm})$ for buffalo, cow and mixed mozzarella cheese respectively.

Table 7. Meltability, Stretchability and Oiling off of mozzarella cheese as affected by milk type during storage at $5 \pm 1{ }^{\circ} \mathrm{C}$

\begin{tabular}{|c|c|c|c|c|c|c|}
\hline \multirow[b]{2}{*}{ Properties } & \multirow[b]{2}{*}{$\begin{array}{c}\text { Storage } \\
\text { period }\end{array}$} & \multicolumn{3}{|c|}{ Treatment } & \multirow[b]{2}{*}{$\mathbf{F}$} & \multirow[b]{2}{*}{$\mathbf{p}$} \\
\hline & & $\begin{array}{l}\text { Buffalo milk } \\
\quad(n=3)\end{array}$ & $\begin{array}{c}\text { Cow milk } \\
(n=3)\end{array}$ & $\begin{array}{l}\text { Mixed milk } \\
\quad(n=3)\end{array}$ & & \\
\hline \multirow{3}{*}{$\begin{array}{l}\text { Meltability } \\
(\mathrm{mm})\end{array}$} & Fresh & $65.0^{\mathrm{a}} \pm 1.0$ & $117.0^{\mathrm{b}} \pm 1.0$ & $90.0^{\mathrm{c}} \pm 1.0$ & $2029.000^{*}$ & $<0.001$ \\
\hline & 14 days & $81.0^{\mathrm{a}} \pm 1.0$ & $146.0^{\mathrm{b}} \pm 1.0$ & $113.0^{\mathrm{c}} \pm 1.0$ & $3169.000^{*}$ & $<0.001$ \\
\hline & 28 days & $105.0^{\mathrm{a}} \pm 1.0$ & $169.0^{\mathrm{b}} \pm 1.0$ & $138.0^{\mathrm{c}} \pm 1.0$ & $3073.000^{*}$ & $<0.001$ \\
\hline \multirow{3}{*}{$\begin{array}{l}\text { Strechability } \\
(\mathrm{cm})\end{array}$} & Fresh & $20.0^{\mathrm{a}} \pm 1.0$ & $75.0^{b} \pm 1.0$ & $62.0^{\mathrm{c}} \pm 1.0$ & $2479.000^{*}$ & $<0.001$ \\
\hline & 14 days & $52.0^{\mathrm{a}} \pm 1.0$ & $96.33^{b} \pm 1.53$ & $81.0^{c} \pm 1.0$ & $1052.846^{*}$ & $<0.001$ \\
\hline & 28 days & $82.0^{\mathrm{a}} \pm 1.0$ & $116.0^{\mathrm{b}} \pm 1.0$ & $96.0^{c} \pm 1.0$ & $876.000^{*}$ & $<0.001$ \\
\hline \multirow{3}{*}{ Oiling off $\%$} & Fresh & $2.68^{\mathrm{a}} \pm 0.16$ & $1.56^{\mathrm{b}} \pm 0.13$ & $2.09^{\mathrm{c}} \pm 0.15$ & $47.088^{*}$ & $<0.001$ \\
\hline & 14 days & $4.38^{\mathrm{a}} \pm 0.19$ & $3.0^{b} \pm 0.16$ & $3.64^{\mathrm{c}} \pm 0.15$ & $55.841^{*}$ & $<0.001$ \\
\hline & 28 days & $6.39^{a} \pm 0.13$ & $4.76^{b} \pm 0.15$ & $5.55^{\mathrm{c}} \pm 0.21$ & $74.333^{*}$ & $<0.001$ \\
\hline
\end{tabular}

F: F test (ANOVA) 
The different superscripts are significant

*: Statistically significant at $\mathrm{p} \leq 0.05$

The improved functionality ( stretchability ) during mozzarella aging may be attributed in part to the age related reduction in concentration of intact para-casein and the increased water binding capacity of the casein. An increase in the water binding capacity of the paracasein is expected to enhance functionality as it is conductive to greater retention of moisture during baking of the Pizza, which in turn limits the occurrence of defects associated with excessive dehydration, such as, burning, crusting and poor flowability.

Sabikhi and Kanawjia (1992) found that the maximum stretchability was observed in the cheese made from the 1:1 admixture of buffalo and goat milk, which had an average arbitrary score of 4.98 . The score reduced to the minimum of 2.0 in the goat milk cheese. The corresponding scores for the control and 3:1 and $1: 3$ blend cheeses were 4.07, 4.72 and 2.93, respectively.

Ghosh and Singh (1996) found that the stretchability of both cow and buffalo milk cheese were good. However, more critically cheese from buffalo milk slightly superior to cow milk. The soft and fine threads of cow milk cheese may be due to lesser protein content.

Guinee, et al., (2001) found a marked increase in stretchability and flowability during the first 30 days of Mozzarella cheese ripening at $0,4,10$, or $15^{\circ} \mathrm{C}$, while it decreased after that, especially at higher storage temperatures.

\section{Oiling off of cheese}

Oiling off is regarded as a defect of this type of cheese when melted on the top of pie. The excessive free oil in Mozzarella cheese is of major quality problem. Table (7) illustrated also values of fat leakage (oiling off) percentage during storage of mozzarella cheese at $5 \pm 1{ }^{0} \mathrm{C}$ for fresh, 14 and 28 days old cheeses. Oiling off $\%$ of fresh and 28 days cheese values were (2.68/ 6.39), (1.56/ 4.76) and (2.09\% and 5.55\%) for buffalo, cow and mixed milk respectively. Obtained result showed that oiling off $\%$ increased gradually as the storage time was advanced for all treatments. These results are in agreement with those reported by ElZoghby (1994) and Abbas (2003).

Abdel El-Gawad (1998) found direct relation between fat content of milk cheese and the leakage of fat. It was higher $(5 \%)$ in $3 \%$ cow milk than $(3 \%)$ buffalo milk. the lowest values $(0.50 \%)$ for $1.5 \%$ buffalo milk. Also storage period led to a marked increase in oiling off of all treatments.
El- Batawy, et al., (2004) found that the higher oiling off in UF-cheese than traditional ones. That generally more fat leakage is found with cheese manufactured from UF-milk during cooking. This may be due to the effects of a coarser protein and fat distribution in the cheese, and the less of casein molecules directly involved in the curd formation. Less casein incorporated into the curd matrix, resulting in less fat, entrapment. The oiling off increased as the storage period advanced, but lower oiling off was occurred after 4 weeks (Ghosh and Singh, 1991).

Helal (2006) found that the type of milk affected the values of fat leakage, and in general buffalo cheese showed the lowest fat leakage in all treatments.

\section{Effect of milk type on the migration of cheese proteins through electrophoretic pattern using PAGE urea.}

Figure (2) illustrate the electrophoretic pattern of different mozzarella cheese on PAGE UREA photogram. It is clear that cow milk cheese sample had numerous bands (layers), which indicate the higher protein hydrolysis followed by mixed milk cheese. The less numerous bands are shown for buffalo milk cheese sample which indicate less protein hydrolysis. Gowning back to (Table 6), the percentage of soluble nitrogen of cow milk cheese is higher than those of buffalo and mixed milk cheese.

Thus the electrophoretic pattern of proteins from different milk showed the presence of $\propto_{\mathrm{s}}$ and $\beta$-casein as the major components and minor fast and slow moving products. The mobility and relative intensity of the $\propto_{\mathrm{s}}$-bands differs according to the type of milk. The results indicate that proteolysis in the $\propto_{\mathrm{s}}$-fraction occurred in all types of milk. The electrophoretic pattern of cheese also showed 1 -2 bands of mobility slower than the B-casein band in cheese from the different milks. In the mean time the intensity of the Bcasein band decreased suggesting that the slow moving product arrised from the proteolysis of this fraction.

El-Zoughby, (1994), found that the proteolysis occurred in Mozzarella cheese made from different milk during storage, and that both $\propto_{\mathrm{s}}$ and B- casein were attacked. This indicate that both residual milk clotting enzymes and plasmin play a prodominat role in the proteolysis of this type of cheese.

The electrophoretic patterns of cheese proteins done by Mostafa, et al., (1996), showed the presence of $\propto_{\mathrm{s}}$ and B- casein as the major components and minor fast and slow moving products. The most obvious difference 
was found in cheese from goats milk which showed minor $\propto_{\mathrm{s}}$-casein band, while B- casein appeared as major constituent of noticeable intensity. After 4 weeks of storage cheese from different treatments showed marked proteolysis as apparent from the number and intensity of the separated protein bands. After 4 weeks of storage marked proteolysis in $\propto_{\mathrm{s}}$-casein and Bcasein was detected in mozzarella cheese for all milk types.

\section{Effect of milk type on the Mozzarella cheese microstructure.}

Scanning electron micrographs of cow, buffalo and mixed mozzarella cheese are shown in Figure (3) understanding the microstructure of mozzarella cheese, particularly how the casein and fat interact during and after manufacture can provide valuable insight into what constitutes a quality product. The buffalo milk curd was found to be less porous when compared with the curd made from the cow milk. This is likely to be a result of the different protein concentrations in the original bovine milks. A higher protein concentration lowers the volume fraction of the aqueous phase, which consequently lowers mean distance between casein micelles and so increases the extent of their subsequent aggregation. The buffalo milk, having the higher protein content, also displays lower gel porosity, with more dense protein fibers, compared with cow milk curd (Ong et al. 2011).
Microscopic scanned investigations done by Mansour, W.M.S (2005) found that buffalo mozzarella cheese showed granular dense protein matrix with smaller and fewer cavities and less fiberness structure. On the other hand, cow mozzarella cheese indicated an opaque structure with some larger pockets and highly fiberness structure with texture.

Buffalo milk cheese protein are more highly aggregated and require more thermal energy to disrupt the aggregates while cow milk cheese had smaller protein aggregates and a more hydrated protein matrix with better melt Brain et al., (1998).

Imm, et al., (2003) found that the small cavities present in cheese at early storage were transformed to elongated fibrous matrix as storage proceeded. The typical fibrous matrix was found at 2 week for bovine mozzarella cheese and 4 week for caprine mozzarella cheese. Bovine mozzarella cheese appeared to have a denser protein matrix at early storage, but fusion and aggregation of small cavities occurred faster than caprine mozzarella cheese as aging continued. The enlargement of cavities during storage might suggest weakening of the protein matrix Poduval and Mistry, (1999).

El- Batawy, et al., (2004). Found that the microstructure of cheese matrix varies in appearance according to the kind of milk and other treatment such as concentration the milk by UF- technique.

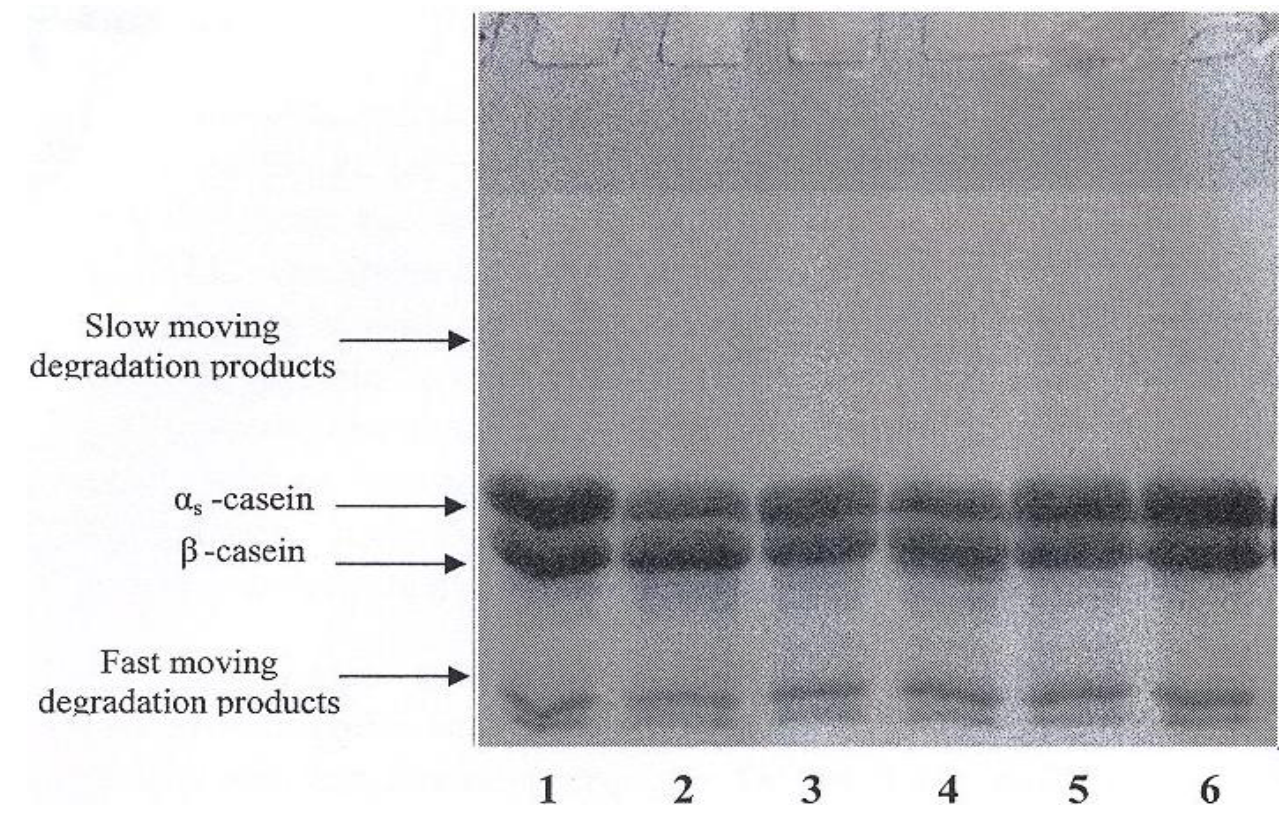

Figure 2. Electrophoretic pattern of fresh Mozzarella cheese as affected by type of milk cheese

$1=$ Cow fresh cheese

$4=$ Buffalo after storage
$2=$ Cow after storage

$5=$ Buffalo + Cow (1:1) fresh cheese
$3=$ Buffalo fresh cheese

$6=$ Buffalo + Cow (1:1) after storage 


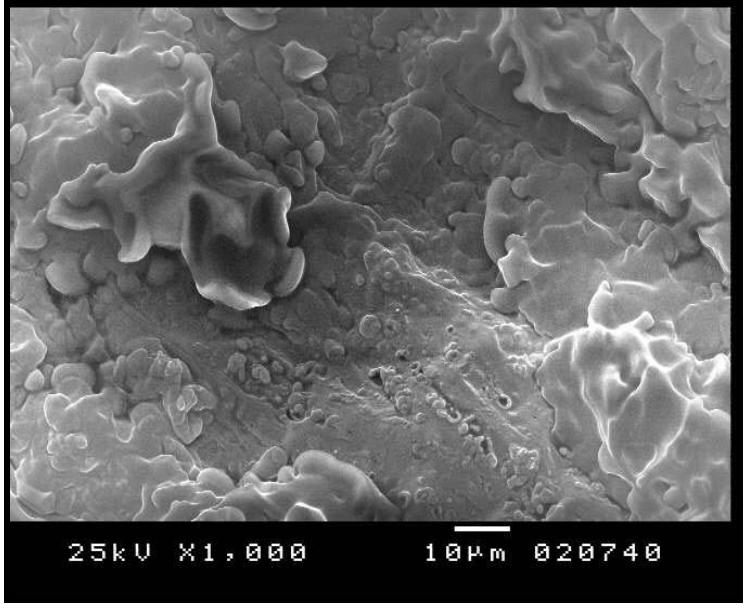

(C)

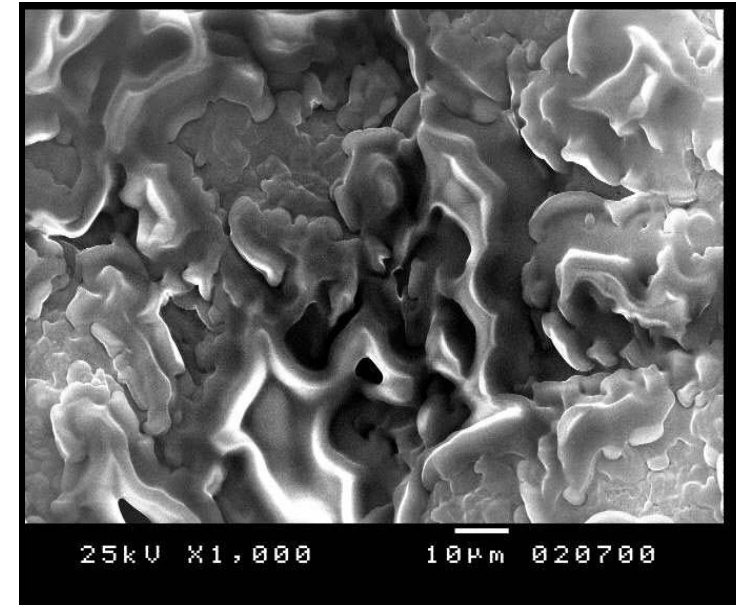

(B)

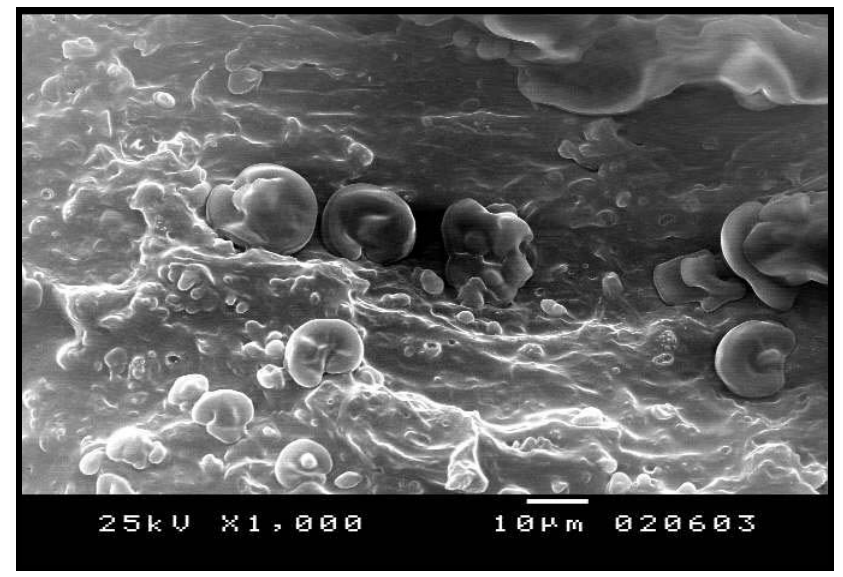

(M)

Figure 3. Scanning electron micrographs of Mozzarella cheese from Cow milk (C), buffalo milk (B) and mixed milk (M). White area: protein matrix, black areas: fat and serum pockets

Effect of milk type on the sensory evaluation of Mozzarella cheese

The ten judges of the dairy science department gave the evaluation marks for appearance, texture and flavor for the unknown samples of mozzarella cheese. According to the method described by Nelson and Trout (1956), 15 point for appearance, 35 points for body and texture and 50 point for flavor. Samples of fresh and 28 day storage cheese were evaluated and results were illustrated in table (8).

Appearance of all cheese slightly decreased as the storage time advanced, while texture and flavor markedly increased as a result of storage. Body and texture of cow milk gained 31 and 33 out of 35 for fresh and stored cheese, while buffalo milk cheese gained 22 and 24 points respectively.
The addition of cow milk to buffalo milk improved the texture to be 25 and 27 points for fresh and 28 days old cheese.

Flavor of cow cheese was highly appreciated by most of the judgers to have 45 and 47 points out of 50 and praised the attractive flavor while they difficulty accepted the flavor of buffalo milk and gave 31 and 36 points for fresh and 28 days old buffalo milk cheese.

They detected the difference between samples of buffalo and mixed milk giving the flavors 36 and 38 points for fresh and 28 days old cheese.

Total scoring points were (88/91), (63/69) and (72/75) point out of 100 for fresh and 28 days old cheese for $\mathrm{C}, \mathrm{B}$ and $\mathrm{M}$ respectively. It is recommended from rheological and sensory evaluation to process mozzarella cheese from cow milk. 
Table 8. Sensory evaluation of Mozzarella cheese made from Buffalo, Cow and mixed milk (1:1) during storage at $5+1{ }^{\circ} \mathrm{C}$

\begin{tabular}{|c|c|c|c|c|}
\hline \multirow{2}{*}{ Properties } & \multirow{2}{*}{$\begin{array}{c}\text { Storage Periods } \\
\text { (Days) }\end{array}$} & \multicolumn{3}{|c|}{ Treatment } \\
\hline & & Buffalo milk & Cow milk & Mixed milk \\
\hline Appearance (15) & \multirow{4}{*}{ Fresh } & 10 & 12 & 11 \\
\hline Body \&Texture (35) & & 22 & 31 & 25 \\
\hline Flavor $(50)$ & & 31 & 45 & 36 \\
\hline Total (100) & & 63 & 88 & 72 \\
\hline Appearance (15) & \multirow{4}{*}{28 day } & 9 & 11 & 10 \\
\hline Body \&Texture (35) & & 24 & 33 & 27 \\
\hline Flavor (50) & & 36 & 47 & 38 \\
\hline Total (100) & & 69 & 91 & 75 \\
\hline
\end{tabular}

El-Zoughby (1994) found that the cow milk cheese gained the highest score when organoleptically evaluated, while buffalo milk cheese comparatively showed the lowest quality among the other treatments, as well surperisely goat milk cheese was accepted by the judges and the goats flavor was not detected. The addition of cow milk to buffalo milk highly improved the quality of mixed milk cheese. Similarly the addition of goat milk to buffalo milk slightly improved the resultant cheese.

Mostafa, et al., (1996) found that the cow milk cheese gained the highest score for organoleptic properties, while buffalo milk cheese showed the lowest quality. Mixing cow milk with buffalo milk highly improved the quality of the cheese. Also mixing of goat milk with buffalo milk slightly improved the quality of its cheese.

El- Batawy, et al., (2004) showed that the traditional cow milk cheese exhibited the highest score than the other treatments. During storage, the total score showed an improvement in all treatments. It could be seen that, the sensory quality of all cheeses gradually improved during the storage period reaching the highest score after 4 weeks of storage.

Sameen, et al., (2008) found that the higher overall acceptance, texture and taste for mixture of cow and buffalo milk cheese than other cheeses. Among sensory attributes the flavor is considered to be the most important factor for determining consumer's response. Flavor of all the treatments improved with storage days because during ripening the metabolic processes are responsible for the basic flavor and texture changes. During cheese ripening when biochemical reactions continued for break down of fat and protein by activity of microbial and residual rennet enzymes more flavoring compound were produced and casein was hydrolyzed which give smooth texture. Barbano et al., (1994).

Abbas, K.A. (2003). Studies on Mozzarella cheese. M. Sc. Thesis, Fac. of Agric. Fayoum, Cairo Univ., Egypt.

Abd El- Gawad, M.A.M. (1998). Manufacture and properties of mozzarella cheese from buffaloes milk. Ph.D. Thesis, Fac. Of Agric Cairo university., Egypt.

Abdel- Kader, Y.I. (1993). Technological studies on the properties of Kachkaval like cheese as affected by direct acidification. Ph. D. Thesis, Fac. Of Agric. Alex. Univ., Egypt

Abd-El-Raheem, A.A. (1957). The determination of calcium and magnesium contents in milk. Neth. Milk and Dairy. J. 11(2): 122 .

Ahmed, S.I. ; Gaucher, F.; Rousseau, E.; Beaucher ; Piot, M.; Grongnet, J.F. and Gaucheron,F.(2008). Effects of acidification on physic-chemical characteristics of buffalo milk, A comparison with cow's milk. Food Chem., 106: 11-17.

Andrews,A.T.(1983). Proteinases in normal bovine milk and their action on caseinate. J.Dairy Res.,50,45-55.

Association of official Analytical chemists (AOAC). (2000). pages $1-80$ in AOAC International, Vol II, $17^{\text {th }}$ ed., Gaithersburg, MD. Atherton, H. V., and J. A. Newlander. 1987. Chemistry and testing of Dairy products, $1^{\text {st }}$ Indian edition, AVI pub. CO. Inc, west-port, CT.

Barbano, D.M., J.J. Yun and P.S. Kindstedt, (1994). Mozzarella cheese making by a stirred curd, no brine procedure. J. Dairy Sci., 77: 2687-2694 (1994).

Brain, M. ; Paulson, B.M. ; Mc Mahon, D. J. and Craig, J.O.(1998). Influence of sodium chloride on appearance, functionality and protein arrangements in nonfat Mozzarella cheese. J. Dairy Sci., 81: 2053.

Egyptian Organization of Standardization and Quality Control (2005). Issued by ministry of industry and technological development. Egypt.

El. Nermr, A.A. (1968). Non enzymatic coagulation of milk and its use in soft cheese making. ph.D. Thesis Fac. of Agric. Cairo Univ. Egypt. 
El-Abbassy, M. Z.; Fayed, H. H. and Farag, A. A. (1991). quality of Mozzarella cheese as affected by certain enzyme preparation. Egyptian Journal of Applied Science, $6(7)$.

El-Batawy,M.A.; Galal,E.A.; Morsy,M.A. and Abbas,Kh.A. (2004). Effect of homogenization on some properties of mozzarella cheese. Egyptian J.Dairy Sci 32:315326(2004).

El-Zoghby, A.S.(1988). Technological studies on hard cheese . M.Sc Thesis. Fac, of Agric., Zagazig Univ., Egypt.

El-Zoghby, Y.I. (1994). Studies on mozzarella cheese. Ph.D. Thesis, Fac. Of Agric Zagazig university., Egypt.

Ghosh, B. C. and Singh, S. (1991). Effect of storage temperatures on sensory, chemical and rheological characteristics of Mozzarella cheese. J. Food Sci and Tech, 28:288.

Ghosh, B. C. and Singh, S. (1992). Storage studies of Mozzarella cheese part I- sensory and rheological characteristics. Indian J. dairy Sci., 45: 199-202.

Ghosh, B. C. and Singh, S. (1996). A comparison of cow and buffalo milk mozzarella cheese. Indian J. Dairy Sci. 49: 38-41. (1996).

Guinee, T.P. ; Feeney, E.P. and Fox, F.P.(2001). Effect of ripening temperature on low moisture Mozzarella cheese. 2. Texture and functionality. Lait, 81:475-485.

Gunasekaran, S.and M.Mehmet, AK.(2003) .Cheese rheology and texture : CRC Pree LLC New York, USA Chapter, 9: 377-397.

Helal, A.M.I.(2006). Manufacturing of Mozzarella Cheese from Cow's and Buffaloe's Milk with Complete Substitution of Milk Fat with Vegetable Oils. Ph. D. Thesis, Fac. of Agric. (damanhour), Alex. Univ., Egypt.

Imm, J.Y. ; Oh, E.J. ; Han, K.S. ; Oh, S. ; Park, Y.W. and Kim, S.H.(2003). Functionality and physic-chemical characteristics of Bovine and Caprine Mozzarella cheese during refrigerated storage. J.Dairy Sci. 86: 27902798.(2003).

Ismail, M.M. and Abdel-Kader, Y.I. (2012). Using of Glucono-Delta- Lactone as acidulant in Mozzarella cheese manufacture. Agricultural Research Journal, Suez Canal University 12 (2): 43- 50.(2012).

Kosikowski, F.V. (1970). Cheese and Fermented Milk Product $2^{\text {nd }}$ edn., Edwards Brothers Inc., Am. Arbor, Michigan, USA.

Kosikowski, F.V. (1982). Cheese and fermented milk foods ( $2^{\text {nd }}$ edn., p405). Ann Arbor, MI: Edwards Brothers. Inc.

Kosikowski, F.V. (1986). New cheese making procedures utilizing ultrafiltration Food Technol. 40:41.

Kotz, S. ; Balakrishnan, N. ; Read, C.B. and Vidakovic, B.(2006). Encyclopedia of statistical sciences. 2nd ed. Hoboken, N.J.: Wiley-Interscience; 2006.

Ling, E.R. (1963). A text book of dairy chemistry. Vol $2.3^{\text {rd }}$ ed., Champon and Hall, London.
Mansour, W.M.S. (2005). Technological studies on Mozzarella cheese from Egyptian buffalo milk. M.Sc Thesis. Fac, of Agric., Ain Shams Univ., Egypt.

McMahon, D.J; Alleyne, M.C.; Fife, R.L. and Oberg, C.J. (1996). Use of fat replacers in low fat mozzarella cheese. J. Dairy sci., 79: 1911-1921.

Mostafa, M. B. M; Shahein, N. M; Abdel-Kader, Y. I and ElZoghby, A. S (1996). Properties of mozzarella cheese as affected by milk type. II- proteolysis, physical properties and organoleptic quality of cheese. Egyptian J. Dairy Sci, 24 (2) 289-296.

Nelson,J.A. and Trout, G.M.(1956). Judging Dairy products 4 th Ed. The Olsen publishing Co. Milwaukee. Wis., 53212.

Olson , N.F., and Price, W.V. (1958). A melting test for pasteurized process cheese spreads. J. Dairy Sci. 41: 9991000 .

Ong, L., Dagastine, R. R., Kentish, S. E., \& Gras, S. L. (2011). Microstructure of milk gel and cheese curd observed using cryo scanning electron microscopy and confocal microscopy. LWT Food Science and Technology, 44(5), 1291-1302.

Ostoeux, R., Guillavne, J. and Laturaze, J. (1958). Separation of volatile aliphatic acids by paper chromatography. J. chromatography 1:70. (C.f. Microbiological and chemical studies on kachkaval - Like cheese. Ph.D. thesis of shoukry, Y.M.R. (1982). Alexandria Univ).

Poduval, V. S. and Mistry, V.V. (1999). Manufacture of reduced fat Mozzarella cheese using ultrafiltered sweet butter milk and homogenized cream. J. Dairy Sci. 82:1-9.

Rayan, A.A., Kalab, M. and Ernstrom, C.A. (1980). Microstructure and rheology of Pasteurized Process Cheese Scanning Electron Microscopy. NO. 3, 635-643.

Rowland, S.J. (1938). The determination of nitrogen distribution on milk. J. Dairy Res. 9, 42-49.

Sabikhi, L. and Kanawjia, S. K. (1992). Effect of admixing of goat and buffalo milks on sensory, compositional and textural characteristics of direct acid Mozzarella cheese. . Indian J. Dairy Sci., 45(10):562-567.

Sabikhi, L. and Kanawjia, S. K. (1993). Effect of type acid on the quality of mozzarella cheese manufactured from admixture of goat and buffalo milks. Indian Journal of Dairy Sci., 46 (1):17-20.

Sameen, A.; Anjum, F.M. ; Huma, N. and Nawaz, H. (2008). Quality Evaluation of Mozzarella Cheese from Different Milk Sources. Rakistan Journal of Nutrrition 7 (6) : 753756 (2008).

Sameen, A.; Anjum, F.M.; Huma, N. and Nawaz, H. (2010). Chemical composition and sensory evaluation of Mozzarella cheese: Influence by milk sources, fat levels, starter cultures and ripening period. Pak. J. Agri. Sci., Vol. 47(1):26-31 (2010).

Scott, R. (1981). Cheese Making Bractice. (Text book). Applied Sci. pub. Ltd. London.

Tamime, A; Younis, M.F., Davies, G and Bradbury, A. (1990). The quality of processed cheese made from 
reconstituted skim milk powder cheese base. Egyptian J. Dairy Sci, 18: 115.

Udabage, P., McKinnon, I. R., \& Augustin, M. A. (2001). Effects of mineral salts and calcium chelating agents on the gelation of renneted skim milk. Journal of Dairy Science, 84(7), 1569-1575.

Zicarelli, L. (2004) .Buffalo Milk: Its properties, Dairy yield and Mozzarella Production. Vet. Res. Comm., 28: 127135.

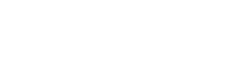

\section{قييم الجوةف جبن الموزاربلا المصنعمن النواع مختلفة من الالبل}

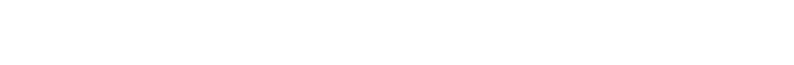

TVFA

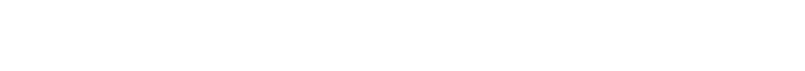

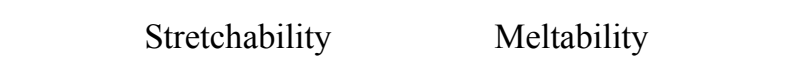
في افصل الدهن Oiling off الكهربه لجزئيت الكازين Electrophoretic pattern فى الجن النانج متشابهة فى عينات جبن الموزاريللا القرى والجلموسى والخليط بنسبة(1:) وفى نهاية فترة التخزين

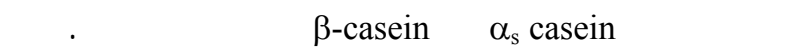
لظهرت درلسة التركيب الدلخله بولنطة الميكروسكوب الالكتروف ان خثرة الجبن المصنع من اللن الجاموسى التل

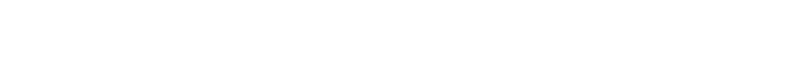
محتوى البروتين العالى فى اللبن الجلموسى الذئى يتمئيز

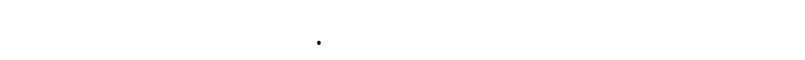

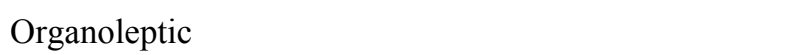
من evaluation بينما الجن الجلموسه حصل على اقل الدرجلت. كما ان

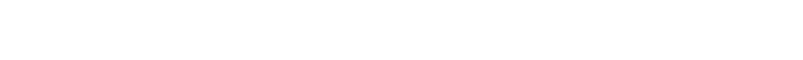

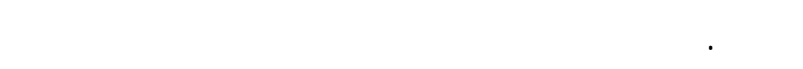
لصناعة البيتزا تتوقف على نوع البن الن المستخدم فى التصنيع.
مت تصنيع جن الموزليللا بالطريقة القليية من لن

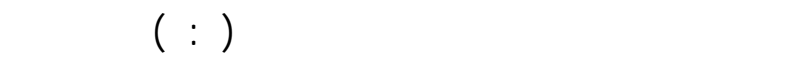

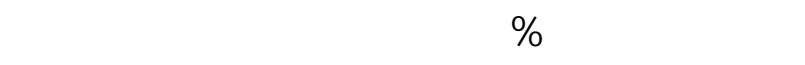

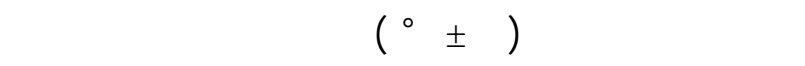
التحليلات الكيميائية والراليولوجية والهسية والتركية التهيب الدقيق والقد اوضحت النتائج المتحصل عليها اله ما يله: كلن فقد الدهن والبروتين فى للشرش وماء العجن للبن

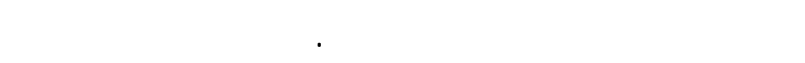
القرى اله الجلموسى ادى اله قلقليل الفقد من الدهن

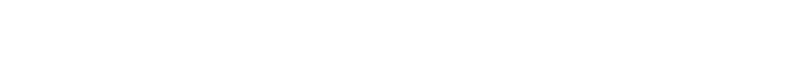

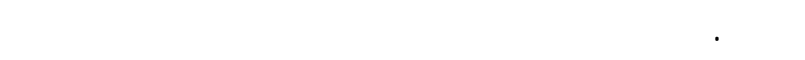

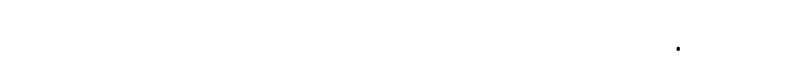

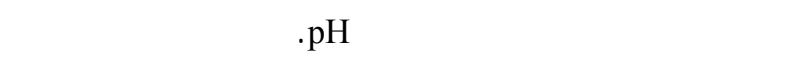

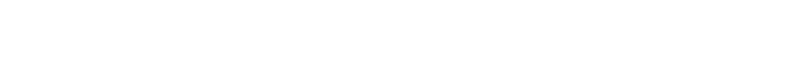

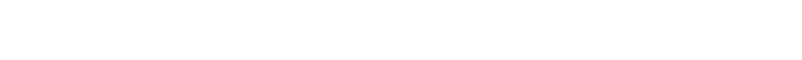

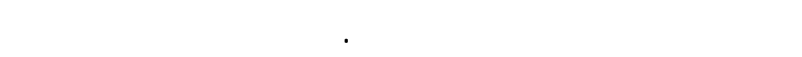
فى اللن القرى والخليط بالمقارنة باللبن الجلموسه. كما

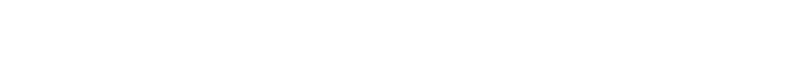
التسوية(النتروجين الذائب، الأحماض الدهنية المالعية الكلية الطيارة) وهذا يرجع لطبيعة الكازين فيه حيث يم تحلله بطئ. ونسبة التهاية 